\title{
Change in demographic patterns of the Doñana Iberian lynx Lynx pardinus: management implications and conservation perspectives
}

\author{
Marcos López-Parra, Leonardo Fernández, Gema Ruiz, José Maria \\ Gil-Sánchez, Miguel Angel Simón, Guillermo López and Pedro Sarmento
}

\begin{abstract}
Over the last 20 years surveys of the population of the Iberian lynx Lynx pardinus in Doñana National Park and its surroundings in Spain have produced estimates of a total population of 50-60 in fragmented patches. The population was estimated to be 26 adults in 2002-2003. Use of camera trapping and other field methods during 2004-2008 allowed us to determine the abundance of the lynx and to estimate demographic statistics. Estimated annual abundance of adult and subadult lynxes averaged 38 individuals (range 35-43). Although the population exhibited a continuous distribution it was concentrated in three major areas, including Doñana National Park, with an average area occupied of $620 \mathrm{~km}^{2}$. Our results suggest that the Doñana Iberian lynx population now has a different structure from that in the 1990 s and in particular a more continuous spatial distribution. These results indicate an improved, but not secure, scenario for the population. The continuous geographical distribution suggests the population is currently less vulnerable to extinction than 10 years ago. Conservation actions now need to focus outside Doñana National Park on the reconversion of pine plantations into original Mediterranean scrubland habitat, and the continuity and intensification of ongoing restocking with rabbits in fenced areas.
\end{abstract}

Keywords Camera trap, Doñana, Iberian lynx, Lynx pardinus, POPAN model, Spain

\section{Introduction}

A understanding of the mechanisms that influence A the distribution and demography of vagile species is fundamental to hypotheses related to resource use and social behaviour, and can be used to guide conservation

Marcos López-Parra, Leonardo Fernández, Gema Ruiz, José Maria GiLSÁNCHEZ and GUILLERMo LóPEZ Empresa de Gestión Medioambiente de la Junta de Andalucia, Johan Gutenberg, Seville, Spain

Miguel Angel Simón Consejería de Medio Ambiente de la Junta de Andalucía Manuel Siurot, Seville, Spain

PEDRo SARMENTo (Corresponding author) CESAM and Departamento de Biologia da Universidade de Aveiro, Campus Universitário de Santiago, 3810193 Aveiro, Portugal. E-mail sarmentop@gmail.com

Received 4 November 2010. Revision requested 23 February 2011. Accepted 15 March 2011. strategies for threatened species (Van Dyke, 2008). Such an approach has been applied to the management of the Iberian lynx Lynx pardinus population in Doñana National Park and surroundings (Gaona et al., 1998; Palomares et al., 2001). The Iberian lynx is categorized as Critically Endangered on the IUCN Red List (Von Arx \& Breitenmoser-Wursten, 2008), with only two remnant reproductive populations: in Doñana National Park and surroundings, and the Andujár-Cardeña Mountains, in Andalusia, southern Spain, comprising a total of c. 150 individuals (Guzmán et al., 2005). The decline of the Iberian lynx was due to persecution, habitat loss and decrease of the populations of its main prey, the European wild rabbit Oryctolagus cuniculus (Delibes et al., 2000).

Data on the Doñana Iberian lynx population have been collected over the last 2 decades (e.g. Palomares et al., 1991; Ferreras et al., 1997), including censuses in the late 1980 s and early 1990s that were based on intensive searches for sign, validated by radio-tracking data (Palomares et al., 1991, 2001). From these surveys it was estimated that there is a total population of 50-60 distributed in an area comprising eight patches of Mediterranean scrubland habitat (Fig. 1).

During 2002-2006 the Regional Environment Ministry of the Andalusia government, in the European Union LIFE project 'Recovering the Iberian lynx populations in Andalusia' (LIFENAT 02/E/8609), established a standardized methodology for lynx surveys, using signs and camera trapping (Guzmán et al., 2005). Independently of this project a camera-trapping survey in 2002-2003 estimated there were c. 26 individuals $>1$ year old, a smaller number compared to earlier studies, and a number that falls below the theoretical threshold of genetic viability (Garrote et al., 2010).

In 2006 the LIFE project Conservation and Reintroduction of Iberian lynx in Andalusia (LIFENAT 06/E/0209) was initiated. As well as recovery of habitat and prey this project aimed to manage the loss of genetic diversity by performing the first translocations and reintroductions of Iberian lynx. As part of this we carried out field work (searching for sign, camera-trapping, direct observations and radio-tracking) to obtain data on lynx demography. Here we describe the results of a 4-year assessment, which was part of both LIFE projects, aimed at estimating Iberian lynx abundance, spatial distribution, and demographic parameters using a capture-mark-recapture 


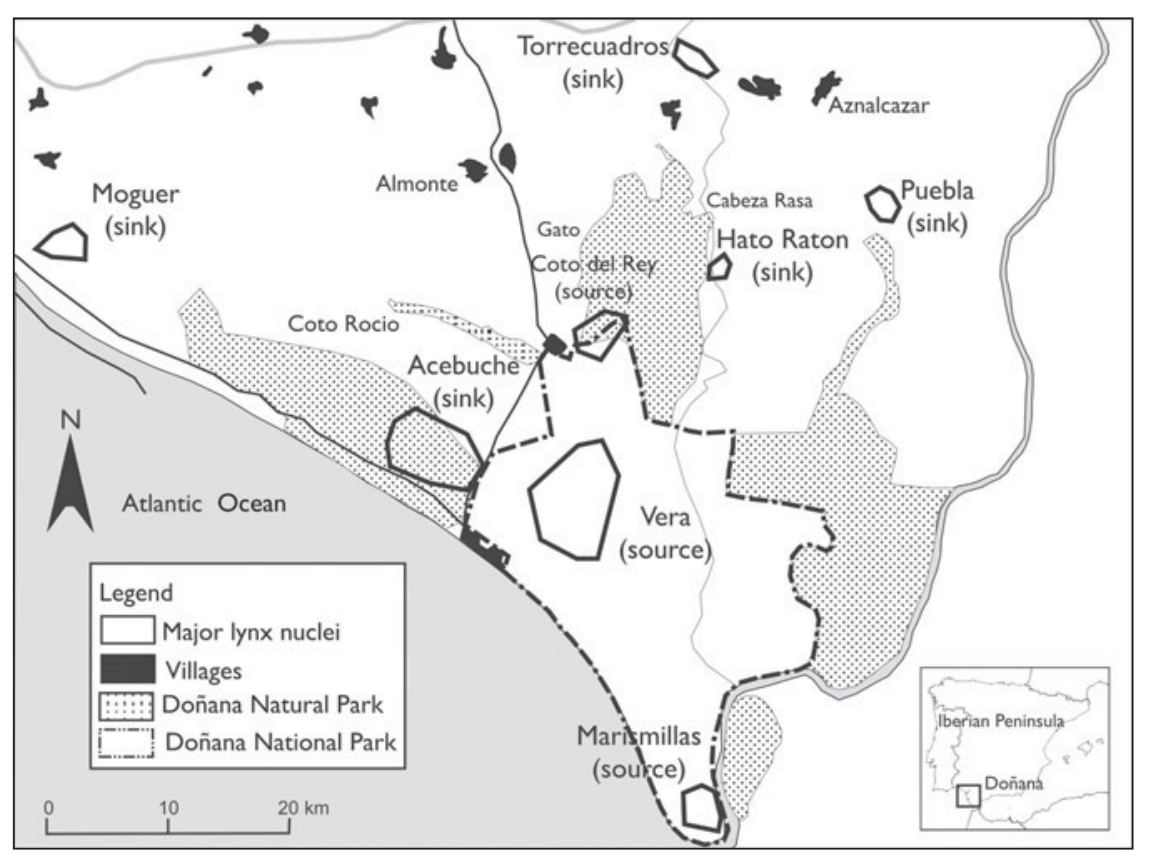

FIG. 1 Study area and spatial distribution of the reproductive nuclei of the Iberian lynx Lynx pardinus identified by previous studies (Ferreras et al., 1997; Gaona et al., 1998; Palomares et al., 2001, 2004). The rectangle on the inset indicates the location of the main map in southern Spain. framework. Our objectives were to determine the abundance and geographical range of the lynx in Doñana, and to estimate population parameters, including sex ratio, population growth and recruitment.

\section{Study area}

Doñana National Park lies in the south-west of the Iberian Peninsula (Fig. 1) at altitudes of $0-50 \mathrm{~m}$, with a Mediterranean subhumid climate $(566 \mathrm{~mm}$ mean annual rainfall) and marked seasonality (Fernández-Delgado, 1997). The c. $2,500 \mathrm{~km}^{2}$ study area comprises three main ecological units: Mediterranean scrubland, marshland and sand dunes. The Park is delimited by the Atlantic Ocean to the south and west, the Guadalquivir River to the east and the western Sierra Morena to the north (Fig. 1). The landscape is fragmented, with c. $50 \%$ of the area covered by a cropland matrix. The remaining landscape is covered by rock roses (Cistus spp.), mastic trees Pistacia lentiscus, cork oak Quercus suber, rock pine plantations Pinus pinea, eucalyptus Eucaplyptus sp. and pastureland. The bestpreserved area is protected by the $550 \mathrm{~km}^{2}$ Doñana National Park, which includes marshes, Mediterranean shrub and a dune system. The $161 \mathrm{~km}^{2}$ Doñana Natural Park, an area with a lower degree of protection, forms a buffer around the National Park. Human use in the Natural Park is more intense, including exploitation of resources such as pine seeds and cork bark, and hunting. Several villages are adjacent to or near both the National and Natural Parks (Fig. 1). These areas support intense human activity, with agricultural and urban development (FernándezDelgado, 1997).

\section{Methods}

From March 2004 to December 2008 we studied the demography of the Iberian lynx using: (1) searches for sign (tracks and scats; Palomares et al., 1991), (2) camera trapping (Karanth \& Nichols, 1998), (3) trapping and radio-tracking (Ferreras et al., 1997), and (4) opportunistic sightings of lynx (Palomares et al., 2001; Table 1).

\section{Sign searching}

We conducted intensive surveys for lynx sign (Table 1). Tracks are easily recognized in the sandy substrate of Doñana and lynx latrines are readily visible (Palomares et al., 1991). We divided the study area into areas where lynx presence was stable and areas irregularly used by lynxes (Guzmán et al., 2005), and defined fixed transects of variable length $(5-12 \mathrm{~km})$ that were regularly surveyed by field workers on foot (Table 1), with 24 and 17 transects in areas of stable and irregular presence, respectively. Transects were surveyed twice per month in areas of stable presence and once per month or every 2 months in irregularly used areas.

\section{Camera trapping}

Camera trapping is effective for monitoring species that can be individually identified (Silveira et al., 2003; Balme et al., 2009). We used six camera makes: (1) 14 CamTrakker analogue (CamTrakker, Watkinsville, USA), (2) 12 DeerCam analogue (DeerCam, Park Lane, USA), (3) 10 Bushnell 2.1MP Model 11.980o (Bushnell Outdoor Products, Overland Park, USA), (4) 10 Stealth Cam 
TABLE 1 Details of searches for signs, camera trapping and box trapping for estimating the abundance of the Iberian lynx Lynx pardinus in Doñana, Spain (Fig. 1), between March 2004 and December 2008.

\begin{tabular}{|c|c|c|c|c|c|c|}
\hline \multirow[b]{2}{*}{ Year } & \multirow[b]{2}{*}{$\begin{array}{l}\text { Sign searching } \\
(\mathrm{km})\end{array}$} & \multicolumn{4}{|c|}{ Camera trapping } & \multirow[b]{2}{*}{$\begin{array}{l}\text { No. of box } \\
\text { trapping sites }\end{array}$} \\
\hline & & $\begin{array}{l}\text { Trap } \\
\text { sites }\end{array}$ & $\begin{array}{l}\text { Trapping } \\
\text { period }\end{array}$ & $\begin{array}{l}\text { Total sampled } \\
\text { area }\left(\mathrm{km}^{2}\right)\end{array}$ & $\begin{array}{l}\text { Trapping effort } \\
\text { (trap-days) }\end{array}$ & \\
\hline 2004 & 144 & 56 & Mar.-Dec. & 905.2 & 639 & 0 \\
\hline 2005 & 122 & 54 & $\begin{array}{l}\text { Jan.-Mar. } \\
\text { Apr.-Aug. } \\
\text { Oct.-Dec. }\end{array}$ & 917.1 & 1,984 & 0 \\
\hline 2006 & 122 & 54 & $\begin{array}{l}\text { Jan.-Mar. } \\
\text { Apr.-Aug. } \\
\text { Oct.-Dec. }\end{array}$ & 932.1 & 1,635 & 0 \\
\hline 2007 & 147 & 52 & All year & $1,278.0$ & 1,566 & 210 \\
\hline 2008 & 153 & 56 & All year & $1,278.0$ & 1,345 & 109 \\
\hline Total & 688 & 212 & & & 7,169 & 319 \\
\hline
\end{tabular}

STC-AD3 (Stealth Cam, Grand Prairie, USA), (5) 20 Leaft River DC-28Us (Leaft River Outdoor Products, Tailorsville, USA), and (6) 30 Canon BF-10 (Canon Spain, Madrid, Spain) with tracking plates. To maximize capture probability the locations of the cameras were determined by the results of searches for sign. Cameras were placed c. $40 \mathrm{~cm}$ above ground and $2-4 \mathrm{~m}$ from the lure, which consisted of Iberian lynx urine sprayed on a piece of cork-tree bark attached to a wooden stake at $40-50 \mathrm{~cm}$ height, or live bait inside a protective cage. Whenever possible we placed the cameras in a grid with a mean spacing distance of $500 \mathrm{~m}$ (Karanth \& Nichols, 1998). However, in some cases the sampling was fragmented into several trapping areas because some of the areas were inaccessible private lands. To determine the size of the sampled area we used half of the mean of the maximum distance moved $(1 / 2$ MMDM) between cameras by each recaptured nondispersing lynx as the buffer radius around each camera station (Silveira et al., 2003).

Individual identification of Iberian lynxes from photographs was based on their distinct coat patterns (Plate 1). The identification process followed the criteria of Jackson et al. (2005), adapted by Sarmento et al. (2009), which included the following items: (1) initial capture: a photograph that we could not positively match with a previously photographed lynx; (2) recapture: a photograph that we could positively match to a previously identified animal; (3) null capture: a photograph that we could not identify as an initial capture or recapture; (4) primary features: the most distinctive features (body areas), and therefore the most useful for identification, for each photograph; (5) secondary features: all useful marks other than primary features; (6) initial capture or recapture determination: positive identification by comparison of the primary feature in each photograph and $\geqslant 2$ secondary features.

\section{Sightings}

When possible lynx were photographed or filmed by field workers, and the location, and number of observed individuals and their age class, and the presence or absence of a radio collar, was noted. Because a substantial number of research personnel are in the field on a daily basis lynx observations are frequently made in Doñana (Palomares et al., 2001).

\section{Capture and radio-telemetry}

During spring 2007 an intense programme of capture and vaccination was carried out to control an outbreak of feline leukaemia virus (Lopez et al., 2009). About $80 \%$ of the total lynx population was captured for vaccination, which allowed us to radio-mark seven individuals. In 2008 we radio-collared a further 11 individuals. Lynx were captured in box traps; trapping procedures and handling of animals followed methods described in López et al. (2009). Captured individuals were fitted with radio collars (Televilt Tellus Collar GPS-GSM, Lindesberg, Sweden, and Wagener Collar, Brenaerham, Germany), with activity monitors. Radio-tagged lynxes were located via triangulation $(n=16)$ or by global positioning system $(n=2)$. The animals were tracked once per day to guarantee data independence and the maximum convex polygon method (MCP) was used to determine the reproductive nuclei by merging the home ranges of reproductive females. These areas were only calculated in 2007 and 2008.

\section{Estimation of population size}

Population estimates were based on adults (usually individuals $>2$ years old) and subadults (at least 6 months 




Plate 1 An example of sequential detections of Iberian lynx Lynx pardinus, with the unique coat patterns of each individual.

(a) Female lynx Teo in January 2004 in east Doñana; (b) Teo and one of her cubs (Alcornoque), in May 2004 in East Doñana;

(c) Alcornoque in a new territory in West Doñana in April 2008; (d) Alcornoque and 2 cubs (E1 and E2) in August 2008.

old) in the pre-dispersal phase (Palomares et al., 2000). An animal was considered an adult when reproduction was confirmed or when camera-trapping or radio-tracking data revealed stable territories for at least 10 months (Fernández et al., 2003). Annual population estimates only considered those animals that were alive from March onwards, coinciding with the beginning of the birth season (Palomares et al., 2005).

We generated capture histories for each individual using the methods of Karanth \& Nichols (1998). Each sampling occasion comprised the period MarchDecember; any animals that died during this time were not considered in the model. We used the superpopulation approach of Schwarz \& Arnason (1996) to estimate abundance. This likelihood-based method estimates a parameter $(N)$, which defines the size of the superpopulation acting as a source of individuals for the population of interest (Kendall \& Bjorkland, 2001). Using this approach four parameters were modelled: (1) apparent survival $(\varphi ; p h i)$, (2) recapture probability $(p)$, (3) probability of new individuals entering the sampled population by birth $(\beta$; pent), and (4) initial superpopulation size $(N)$. We used the POPAN model type in MARK (White \& Burnham, 1999), which provides a parameterization of the Jolly-Seber model (Schwarz \& Arnason, 1996) that is particularly robust. Model selection was performed using Akaike's information criterion corrected for small sample size ( AIC $_{c}$; Akaike, 1973). Models with $\triangle \mathrm{AICc}$ values $\leqslant 2$ from the most parsimonious model were considered strongly supported. We generated a total of eight models; this represents all possible combinations considering the possibility of all parameters being constant or varying with time except for $N$, which represents the initial superpopulation size and has only a single value. We then estimated the number of animals in the population on each occasion $(\hat{N})$ as a derived parameter, considering all age and sex classes. Because we knew the ratios of each age and sex class for each year (as a result of camera trapping, box trapping and direct observations) we could estimate the numbers of each age and sex class $\left(\hat{N}_{t}\right)$ by multiplying this ratio by $\hat{N}$ and by the highest and the lowest value of the $95 \%$ confidence interval (CI).

We calculated exponential rates of increase $(r)$ between annual abundance estimates $\left(N_{\mathrm{t}}\right.$ and $\left.N_{\mathrm{t}+1}\right)$ for each year as described by Caughley (1977): $r=\ln \left(N_{\mathrm{t}+1} / N_{\mathrm{t}}\right)$. Changes in population size were expressed as the percent of increase (or decrease): percentage change $=\left(e^{r}-1\right)$. 
TABLE 2 Lynx presence data obtained during 2004-2008, used for estimating the abundance of the Iberian lynx in Doñana, Spain.

\begin{tabular}{|c|c|c|c|c|c|c|c|c|c|}
\hline Year & $\begin{array}{l}\text { No. } \\
\text { photographed }\end{array}$ & $\begin{array}{l}\text { No. } \\
\text { photographed per } \\
100 \text { trap-days }\end{array}$ & $\begin{array}{l}\text { No. } \\
\text { captured }\end{array}$ & $\begin{array}{l}\text { No. } \\
\text { captured per } \\
100 \text { trap- } \\
\text { days }\end{array}$ & $\begin{array}{l}\text { Cumulative no. } \\
\text { of radio-tracked } \\
\text { lynxes }\end{array}$ & $\begin{array}{l}\text { Lynx } \\
\text { sightings }\end{array}$ & $\begin{array}{l}\text { No. of } \\
\text { identified } \\
\text { individuals* }\end{array}$ & $\begin{array}{l}\text { Lynx } \\
\text { tracks }\end{array}$ & $\begin{array}{l}\text { Lynx } \\
\text { scats }\end{array}$ \\
\hline 2004 & 20 & 3.13 & & & & 7 & 34 & 187 & 106 \\
\hline 2005 & 31 & 1.56 & & & & 11 & 40 & 158 & 113 \\
\hline 2006 & 22 & 1.34 & & & & 17 & 34 & 223 & 183 \\
\hline 2007 & 24 & 1.53 & 30 & 1.52 & 7 & 19 & 37 & 103 & 260 \\
\hline 2008 & 23 & 1.71 & 17 & 1.74 & 18 & 9 & 32 & 125 & 160 \\
\hline Total & 59 & 1.85 & 33 & 1.12 & 18 & 63 & 73 & 174 & 796 \\
\hline
\end{tabular}

${ }^{\star}$ Includes additional observations from lynx sightings and captures in traps

\section{Range}

The geographical locations of lynx photographs, sightings and signs, and from radio telemetry in 2007-2008, allowed us to determine the range of the population in each year. All data were georeferenced and mapped using ArcInfo v. 9.2 (ESRI, Redlands, USA). For each year we generated a distribution map using a $2 \times 2 \mathrm{~km}$ UTM grid. We classified each square as either regularly used by lynx (cells occupied for $>6$ consecutive months) or sporadically used by lynx (cells occupied for $<6$ consecutive months).

\section{Reproduction, population losses and adult recruitment}

We assessed reproduction and recruitment using the camera-trapping data and field observations. The detection of females with cubs allowed us to calculate reproductive rates, the number of post-denning cubs (usually $>3$ months old) and breeding success. Adult recruitment was assessed using the same procedure. We defined recruitment rate as the number of lynxes of both sexes that reached adulthood, as previously defined. Population losses accounted for individuals found dead in the field and individuals that died during the radio-tracking survey. A radio-collared individual was considered a mortality event if no locations had been recorded for $>_{1}$ year and the individual was not subsequently recaptured or resighted.

\section{Dispersal and flux of individuals}

We considered that lynxes dispersed when they left the maternal home range and did not return for at least 1 month (Ferreras et al., 2004). For calculating mean juvenile dispersal distance we only used the data for animals that were marked with radio collars $(n=5)$, and define the distance between the point of first detection (near the dens) to the arithmetical centre of activity of the new home range.

\section{Results}

From March 2004 to December 2008 we identified a total of 59 adult or subadult lynxes (20 males and 39 females) using 2,336 photographs (Table 2); i.e. a success of 1.85 individual captures per 100 trap-days (Table 2). Lynxes were photographed at all 212 trapping stations. Box-trapping resulted in a total of 33 captured animals, with a trapping success of 1.12 individual lynxes per 100 trap-days (Table 2). Of the 33 captured animals 10 were not photographed by camera traps. We obtained ad hoc photographic data from field researchers that allowed us to identify another four individuals, which were incorporated into the model. We therefore detected a total of 73 adult and subadult lynxes ( 28 males and 45 females; Table 2).

\section{Population estimation}

The most appropriate POPAN model was $\{p h i(t) p()$. pent(.) $N\}$ (Table 3), with time affecting apparent survival. This parameter averaged $0.72 \pm \mathrm{SE} 0.11$ ), peaking in 2007 $(\varphi=0.8 \pm$ SE 0.1$)$ and reaching the lowest value in 2008 $(\varphi=0.7 \pm$ SE 0.1). Besides apparent survival the parameters estimated with this model were recapture probability $(p=1.0 \pm$ SE 0.0$)$, probability of entry $(\beta=1.0 \pm$ SE 0.1$)$ and the initial superpopulation size $(\hat{N}=36.0 \pm \mathrm{SE}$ o.o $)$.

Animals were concentrated in three main areas (Fig. 2): west Doñana (Moguer-Coto Rocío-Almonte), Doñana National Park, and east Doñana (Cabeza Rasa-Hato RatónGato-Aznalcazar). Using the POPAN model the estimate of the Iberian lynx population (adults and subadults) ranged from a mean of 35.0 (95\% CI 32.0-36.0) in 2008 to 43.0 (95\% CI 40.0-44.0) in 2005 (Table 4). Amongst adults females significantly outnumbered males $\left(\chi^{2}=2.0\right.$, $\mathrm{P}=0.04)$. Sex ratio differed significantly from the expected $1: 1$ ratio in 2004, 2007 and $2008(\mathrm{P}=0.03, \mathrm{P}=0.02$ and $\mathrm{P}=0.01$, respectively; Table 5). Amongst subadults females also significantly outnumbered males $\left(\chi^{2}=1.6\right.$, $\mathrm{P}=0.05)$. We did not observe significant differences in the structure of subpopulations (ANOVA, $F_{2,45}=0.01$, 
TABLE 3 Model selection statistics for open-population analysis using the POPAN model on capture-recapture data for the Iberian lynx in Doñana, Spain, during 2004-2008 (Table 2).

\begin{tabular}{|c|c|c|c|c|c|c|}
\hline Model $^{\star}$ & $\mathrm{AIC}_{\mathrm{c}}$ & $\Delta \mathrm{AIC}_{\mathrm{c}}$ & $\mathrm{AIC}_{\mathrm{c}}$ weight & $\begin{array}{l}\text { Model } \\
\text { likelihood }\end{array}$ & No. parameters & Deviance \\
\hline$\{$ phi(t)p(.)pent(.) N\} & 344.56 & 0.00 & 0.94 & 1.00 & 7 & 0.00 \\
\hline$\{$ phi(.) p(.) pent(.) $N\}$ & 645.46 & 5.67 & 0.06 & 0.02 & 4 & 0.00 \\
\hline$\{p h i(t) p(t)$ pent(.) $N\}$ & $3,187.72$ & 90.58 & 0.00 & 0.00 & 11 & 59.28 \\
\hline$\{p h i(t) p($.$) pent (t) N\}$ & $3,187.72$ & 90.58 & 0.00 & 0.00 & 10 & 66.29 \\
\hline$\{p h i() p.($.$) pent (t) N\}$ & $3,187.72$ & 94.98 & 0.00 & 0.00 & 7 & 66.29 \\
\hline$\{p h i() p.(t) \operatorname{pent}(t) N\}$ & $3,187.72$ & 94.98 & 0.00 & 0.00 & 11 & 62.17 \\
\hline$\{p h i(t) p(t) \operatorname{pent}(t) N\}$ & $3,187.72$ & 94.98 & 0.00 & 0.00 & 14 & 62.17 \\
\hline$\{$ phi(.) p(t) pent(.) $N\}$ & $3,187.72$ & 94.98 & 0.00 & 0.00 & 8 & 62.17 \\
\hline
\end{tabular}

${ }^{*} p h i$, apparent survival; $p$, recapture probability; pent, probability of new individuals entering the sampled population; $N$, initial superpopulation size. The parameters were modelled such that they could be constant over sampling occasions (.) or varying with time ( $t$ ), except for $N$.

$\mathrm{P}=0.99$ ) or annual exponential rates of increase (ANOVA, $\left.F_{2,45}=0.11, \mathrm{P}=0.79\right)$, for the three population nuclei.

\section{Range}

During the study period the most relevant changes in the occupied area were a minor constriction of the west Doñana nucleus, a shift to the north-east of the east Doñana nucleus, and an increase in the area of the Doñana National Park nucleus (Fig. 2). The regular range averaged $620 \pm \mathrm{SE}$ $107 \mathrm{~km}^{2}$ ), with an increasing trend during the study (Table 5).

\section{Reproduction, population losses and adult recruitment}

We detected 17 reproductive females, corresponding to $77.3 \%$ of all detected adult females, and 78 cubs ( $>3$ months old; Fig. 2). According to the camera-trap photographs there was an annual mean of $1.8 \pm \operatorname{SE} 0.2(n=5$, range $1-3)$ post-denning cubs per reproductive female, and no significant differences either between the three areas (ANOVA, $F_{2,35}=0.71, \mathrm{P}=0.50$ ) or between the annual number of post-denning cubs (ANOVA, $F_{2,12}=1.50$, $\mathrm{P}=0.26)$. There was an annual mean of $15.6 \pm \mathrm{SE} 2.5$ cubs $>3$ months old $(n=5$, range 9-24), and a mean of $8.4 \pm$ SE 0.5 reproductive females $(\mathrm{n}=5$, range $7-10)$, which represents an annual mean of $60.0 \pm \mathrm{SE} 3.2 \%$ of the adult females $(\mathrm{n}=5$, range 50.0-67.0\%). There was a steady increase in the number of post-denning cubs from 2005, peaking in 2008 with a total of 24 (Fig. 2).

We documented a total of 37 mortality events in all age and sex classes combined and four individuals were removed for the captive breeding programme (one male cub and three female cubs). Additionally, 27 individuals disappeared and were considered dead. Female losses averaged 5.2 \pm SE 1.1 per year $(n=26$, range $2-8)$ and male losses averaged $3.8 \pm$ SE 1.2 per year $(n=19$, range $2-8)$. The mortality ratios indicated that a mean of $15.0 \pm$ SE $7.0 \%$ of adult females $(\mathrm{n}=5$, range $0.0-41.1 \%), 26.0 \pm$ SE $6.0 \%$ of the adult males ( $\mathrm{n}=5$, range $8.2-42.0 \%)$, and $8.0 \pm$ SE 5.6\% of all lynxes $(n=5$, range $7.1-33.0 \%)$ were lost from the population. There were no significant differences in the percentage of losses within the different population classes between areas (ANOVA, $F_{3,33}=0.68, \mathrm{P}=0.52$ ). Known mortality causes were mostly road collisions $(35.3 \%$ of the known mortality) and diseases $(55.5 \%)$ such as feline leukaemia virus (FeLV).

The estimated annual recruitment to the adult male population was low during most of the study period (mean $=2.20 \pm \mathrm{SE} 0.7, \mathrm{n}=5$, range $0-4)$ except for 2005, when an estimated recruitment rate higher than population losses was recorded (Table 5). In subsequent years, as the number of adult males decreased, losses in this age class were always above the recruitment level (Table 5). Although the recruitment rate increased from 2007 to 2008, with one adult male being translocated from the Andújar nucleus, the population continued to decrease because the FeLV outbreak caused the death of five adult males (López et al., 2009). Annually, there was a mean loss of $2.8 \pm \mathrm{SE} 1.0$ individuals in the adult male population $(\mathrm{n}=14$, range $0-5)$.

There was a mean recruitment of $3.4 \pm$ SE 0.4 adult females per year ( $\mathrm{n}=17$, range $3-5)$, which was relatively constant during the 5-year study period. In 2004, 2007 and 2008 recruitment exceeded population losses, with an increase of adult females (Table 5).

\section{Flux of individuals}

Of those lynx born since 2004, 12 reached adulthood (four males and eight females). Seven were born in west Doñana (58\%), three in Doñana National Park (25\%), and two in east Doñana (17\%). Of the 12 lynx four (33.3\%) established their territory in their birthplace (two males and two females, all from west Doñana), and 7 (58.3\%) dispersed to other areas (Fig. 3). The predominant dispersal direction was towards 



FIG. 2 Spatial distribution and demography of the Iberian lynx nuclei in Doñana, Spain, from 2004 to 2008.

the National Park, where two males and two females established their adult territories (Fig. 3). Adult dispersal was also observed: two males and one female moved their territories (Fig. 3). Mean dispersal distance was $24.7 \pm \mathrm{SE}$ $3.4 \mathrm{~km}(\mathrm{n}=12$ range $3.6-43.6)$.

\section{Discussion}

Our results demonstrate that photographic capture-markrecapture sampling can be used for estimating Iberian lynx abundance, particularly in combination with sign surveys. The high recapture probability $(p=1.0)$ and narrow confidence intervals indicate the effectiveness of the methods used. We only detected two unknown adults in the population (i.e. individuals that were not detected before reaching adulthood). The intensive use of camera-trapping allowed us to assess the number of reproductive females and post-denning cubs, and dispersal and adult recruitment, knowledge of which are important for population management. 
TABLE 4 Abundance $(\hat{N} \pm \mathrm{SE})$, with 95\% CI, change in population size from previous year, and exponential rates of increase $(r)$ of adult males, females and overall, of subadult males and females, and of the total population of Iberian lynxes in Doñana, Spain over 2004-2008, estimated by the POPAN model type $\{$ phi(t) $p($.) pent(.) $N\}$.

\begin{tabular}{|c|c|c|c|c|c|}
\hline & 2004 & 2005 & 2006 & 2007 & 2008 \\
\hline No. of adult males \pm SE & $8 \pm 0.33$ & $12 \pm 0.42$ & $9 \pm 0.21$ & $7 \pm 1.02$ & $6 \pm 2.11$ \\
\hline $95 \% \mathrm{CI}$ & $8-8$ & $12-12$ & $9-9$ & $6-7$ & $5-7$ \\
\hline$\%$ change & & 49.81 & -24.93 & -22.16 & -14.25 \\
\hline$r$ & & 0.41 & -0.29 & -0.25 & -0.15 \\
\hline No. of adult females \pm SE & $16 \pm 1.33$ & $15 \pm 1.53$ & $13 \pm 1.46$ & $13 \pm 0.22$ & $16 \pm 0.24$ \\
\hline $95 \% \mathrm{CI}$ & $16-17$ & $14-16$ & $12-13$ & $12-13$ & $16-16$ \\
\hline$\%$ change & & -6.23 & -13.30 & 0.00 & 23.00 \\
\hline$r$ & & -0.06 & -0.14 & 0.00 & 0.21 \\
\hline No. of adults \pm SE & $24 \pm 0.83$ & $27 \pm 0.98$ & $22 \pm 0.84$ & $20 \pm 0.62$ & $22 \pm 1.18$ \\
\hline $95 \% \mathrm{CI}$ & $24-25$ & $26-28$ & $21-22$ & $18-20$ & $21-23$ \\
\hline$\%$ change & & 12.46 & -18.47 & -9.06 & 10.00 \\
\hline$r$ & & 0.12 & -0.20 & -0.10 & 0.10 \\
\hline No. of subadult males \pm SE & $5 \pm 1.20$ & $6 \pm 1.01$ & $7 \pm 1.11$ & $9 \pm 1.56$ & $5 \pm 1.46$ \\
\hline $95 \% \mathrm{CI}$ & $4-5$ & $5-6$ & $6-7$ & $8-10$ & $4-5$ \\
\hline$\%$ change & & 19.93 & 16.61 & 28.47 & -44.34 \\
\hline$r$ & & 0.18 & 0.15 & 0.25 & -0.59 \\
\hline No. of subadult females \pm SE & $7 \pm 1.33$ & $10 \pm 1.39$ & $7 \pm 1.22$ & $10 \pm 1.56$ & $8 \pm 1.48$ \\
\hline $95 \% \mathrm{CI}$ & $6-7$ & $9-10$ & $6-7$ & $9-10$ & $7-8$ \\
\hline$\%$ change & & 42.70 & -29.92 & 42.70 & -19.95 \\
\hline$r$ & & 0.36 & -0.36 & 0.36 & -0.22 \\
\hline Total population $\pm S E$ & $36 \pm 1.12$ & $43 \pm 1.00$ & $36 \pm 0.95$ & $39 \pm 1.24$ & $35 \pm 1.37$ \\
\hline $95 \% \mathrm{CI}$ & $34-37$ & $40-44$ & $33-36$ & $37-40$ & $32-36$ \\
\hline$\%$ change & & 19.38 & -16.23 & 8.31 & -10.23 \\
\hline$r$ & & 0.18 & -0.18 & 0.08 & -0.11 \\
\hline
\end{tabular}

TABLE 5 Density estimates, recruitment, losses and sex ratio of the adult population of the Iberian lynx in Doñana, Spain, over 2004-2008.

\begin{tabular}{|c|c|c|c|c|c|c|}
\hline & 2004 & 2005 & 2006 & 2007 & 2008 & Total \\
\hline Estimated regular range $\left(\mathrm{km}^{2}\right)$ & 484 & 676 & 552 & 632 & 760 & \\
\hline \multicolumn{7}{|l|}{ Adult males } \\
\hline Individuals per $100 \mathrm{~km}^{2 *}$ & 1.65 & 1.76 & 1.63 & 1.10 & 0.78 & \\
\hline Recruitment & 2 & 4 & 2 & 0 & 3 & 11 \\
\hline Losses & 2 & 0 & 5 & 2 & 5 & 14 \\
\hline \multicolumn{7}{|l|}{ Adult females } \\
\hline Individuals per $100 \mathrm{~km}^{2 \star}$ & 3.31 & 2.22 & 2.36 & $2-06$ & 2.11 & \\
\hline Reproductive females (\%) & 56 & 47 & 62 & 62 & 63 & \\
\hline Recruitment & 5 & 3 & 3 & 3 & 3 & 17 \\
\hline Losses & 2 & 4 & 5 & 2 & 0 & 13 \\
\hline \multicolumn{7}{|l|}{ Total adults } \\
\hline Individuals per $100 \mathrm{~km}^{2 \star}$ & 3.28 & 3.34 & 2.69 & 2.51 & 2.35 & \\
\hline Estimated sex ratio ( $\mathrm{f}: \mathrm{m}$ ) & 2.00 & 1.25 & 1.44 & 1.86 & 2.67 & \\
\hline
\end{tabular}

${ }^{\star}$ For calculating the density we only considered the areas of regular range (areas where the presence of the lynx was stable)

\section{Population structure past and present}

Our results suggest that the Doñana lynx population now exhibits a different spatial dynamic to that described in previous studies (Palomares et al., 1991; Ferreras et al., 1997, 2004). These earlier studies found that the Doñana lynx population had been isolated for c. 50 years and comprised
50-60 individuals in eight subpopulations (Ferreras et al., 2001): three inside Doñana National Park that acted as sources (Vera, Marismillas and Coto del Rey) and five outside the Park identified as sinks, with a minor contribution to both the occupied area and number of individuals (Acebuche, Moguer, Hato-Ratón, Torrecuadros and Puebla; Palomares et al., 1991). Thus the lynx population 


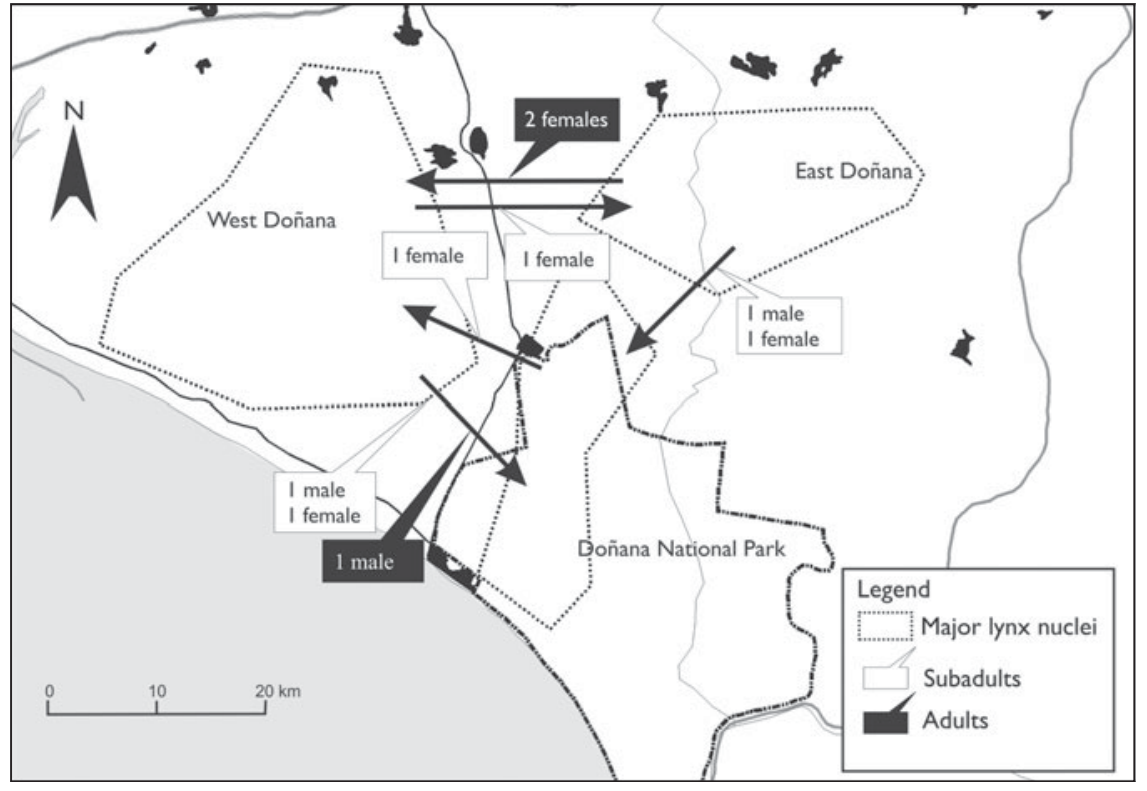

FIG. 3 Flux of individuals, observed by camera-trapping and radio-tracking, between the three Iberian lynx population nuclei in Doñana, Spain, during 2004-2008. exhibited a typical metapopulation structure in the sense of 'a group of interconnected populations that function as a unit' (Hanski, 1999). The results obtained by Garrote et al. (2010) for 2002-2003 indicated a significant decrease in adult numbers, which was confirmed by our data.

The Doñana National Park nucleus continues to be an important area for conservation of the Iberian lynx. In the last year of our study five reproductive females were present and at least 11 cubs were born. Of the five females two were born outside the Park (one each in west and east Doñana). One of the two males living in the Park came from east Doñana and the other was translocated from eastern Sierra Morena. This reveals the importance of the peripheral areas for maintaining the Doñana National Park nucleus. In the other two nuclei only four adults were detected in 2002 (Guzmán et al., 2005) whereas a total of 13 adults were identified in 2008. This corresponds to an increase of $162 \%$ in 6 years, an apparent result of the work of the LIFE conservation project. At least one of the new territories located outside the Park was occupied by a female born in the Park, thus confirming the existence of movement of individuals among the three nuclei. The areas outside the Park, which $<10$ years ago acted as sinks (Palomares et al., 1991; Gaona et al., 1998; Ferreras et al., 2001, 2004), now seem to be sources, not only to the Park but also among themselves. This movement facilitates compensation for population losses, thus maintaining the stability of the Doñana lynx population. Any catastrophic event in one of the three nuclei could therefore now be potentially compensated by the other nuclei (as happened during the FeLV outbreak in 2007).

In the 1990s the adult sex ratio was estimated from radiotracking to be $1.23: 1$, close to the expected $1: 1$ ratio (Gaona et al., 1998). This is similar to that in our study in 2005 and
2006 but considerably lower than in 2007 and 2008. Male numbers decreased $22 \%$ in 2007 and $14 \%$ in 2008 , whereas female numbers were constant in 2007 and increased by $38 \%$ in 2008. This skewed sex ratio was mostly caused by the FeLV outbreak (Lopéz et al., 2009).

\section{Conservation perspectives}

The conservation of the Doñana lynx population is hampered by a low number of individuals (Ferreras et al., 2001), high mortality (Ferreras et al., 1992, 2004), low rabbit density (Ferreras et al., 2001), habitat fragmentation (Ferreras et al., 2001) and diseases (Lopéz et al., 2009). Earlier studies found that human-caused mortality, principally illegal hunting, was the main cause of lynx mortality in Doñana (Ferreras et al., 1992) but in our study disease was the most important mortality factor ( $60 \%$ of the known deaths). We found that illegal hunting is now of minimal importance, with only a single case during 2004-2008. This difference appears to be a result of a change in the attitudes of the general population and hunters, achieved through the communication strategy of the LIFE project, and the greater effectiveness of surveillance. Road mortality is still a significant problem, with a higher effect on subadults, probably as a result of dispersion, and is a factor that needs more effective actions to control it. According to Ferreras et al. (2001) an increase of the carrying capacity by active management should be a conservation objective for the source populations (Vera, Marismilla, Coto del Rey) but not for the sink populations (Moguer and Acebuche in west Doñana, and Torrecuadros, Puebla and Hato-Ratón in east Doñana). However, the population structure no longer consists of small, peripheral populations weakly 
connected with the main sources. The dynamic process of extinction and recolonization described by Ferreras et al. (2001) seems to have changed and consequently a different conservation strategy should now be considered. All the areas seem to have significant importance in terms of number of individuals, reproduction and geographical range. The amount of available habitat, particularly in west Doñana could be a critical condition for the recovery and expansion of the population.

The management actions applied over the last decade to reverse the decline of the Doñana Iberian lynx population included: (1) restocking with rabbits (Moreno et al., 2004), (2) habitat improvement for rabbits (Moreno \& Villafuerte, 1995), (3) construction of artificial breeding dens for lynx (Simón, 2008), (4) supplementation with translocated lynx (Ruiz, 2008), (5) establishment of enclosures containing rabbits, with access for lynx (López-Bao et al., 2010), (6) disease management (Lopéz et al., 2009), and (7) fauna underpasses, road signs and speed bumps. Conservation efforts now also need to be intensive outside the National Park, where $56 \%$ of the cubs were born during our study period, particularly in the areas of west Doñana. In these areas, with c. 18,00o ha of potential habitat, conservation actions need to focus on the reconversion of pine plantations into Mediterranean scrubland habitat, and the intensification of ongoing restocking of fenced areas with rabbits (Palomares et al., 2000, 2001). These will increase habitat carrying capacity by increasing the number of territories and decreasing territory size. It is also important to connect the Doñana population with other potential lynx areas, particularly new populations founded by reintroduction, to reduce extinction risk.

\section{Acknowledgements}

This research was funded by LIFE project LIFE-NAT 06/E/ 000209. Catarina Eira, Joana Cruz and Carlos Fonseca helped with the revision of the article. We acknowledge in particular the Doñana field personnel.

\section{References}

Aкаike, H. (1973) Information theory and an extension of the maximum likelihood principle. In International Symposium on Information Theory (eds B.N. Petran \& F. Csaki), pp. 267-281. Akademiai Kiadi, Budapest, Hungary.

Balme, G.A., Hunter, L.T.B. \& Slotow, R. (2009) Evaluating methods for counting cryptic carnivores. Journal of Wildife Management, 73, 433-441.

Caughley, G. (1977) Analysis of Vertebrate Populations. John Wiley and Sons, New York, USA.

Delibes, M., Rodríguez, A. \& Ferreras, P. (2000) Action Plan for the Conservation of the Iberian Lynx (Lynx pardinus) in Europe.
Council of Europe Publishing, Nature and Environment, Strasbourg, France.

Fernández, N., Delibes, M., Palomares, F. \& Mladenoff, D.J. (2003) Identifying breeding habitat for the Iberian lynx: interferences from a fine-scale spatial analysis. Ecological Applications, 13, 1310-1324.

Fernández-Delgado, C. (1997) Conservation management of a European Natural Area: Doñana National Park, Spain. In Principles of Conservation Biology. 2nd ed. (eds G.K. Meffe \& C.R. Carroll), pp. 458-467. Sinauer, Sunderland, USA.

Ferreras, P., Aldama, J.J., Beltrán, J.F. \& Delibes, M. (1992) Rates and causes of mortality in a fragmented population of Iberian lynx Felis pardina Temminck, 1824. Biological Conservation, 61, 197-202.

Ferreras, P., Beltrán, J.F., Aldama, J.J. \& Delibes, M. (1997) Spatial organization and land tenure system in the endangered Iberian lynx (Lynx pardinus Temminck, 1824). Journal of Zoology, 243, 163-189.

Ferreras, P., Delibes, M., Palomares, F., Fedriani, J.M., Calzada, J. \& Revilla, E. (2004) Proximate and ultimate causes of dispersal in the Iberian lynx Lynx pardinus. Behavioral Ecology, 15, 31-40.

Ferreras, P., Gaona, P., Palomares, F. \& Delibes, M. (2001) Increase numbers or reduce mortality? Implications from a population viability analysis of the Iberian lynx. Animal Conservation, 4, 265-274.

Gaona, P., Ferreras, P. \& Delibes, M. (1998) Dynamics and viability of a metapopulation of the endangered Iberian lynx (Lynx pardinus). Ecological Monographs, 68, 349-370.

Garrote, G., Ayala, R.P., Pereira, P., Robles, F., Guzmán, N., GARCíA, F. et al. (2010) Estimation of the Iberian lynx (Lynx pardinus) population in the Doñana area, SW Spain, using capturerecapture analysis of camera-trapping data. European Journal of Wildlife Research, 57, 355-352.

Guzmán, J.N., García, F., Garrote, G., Ayala, R. \& Iglesias, C. (2005) El lince ibérico (Lynx pardinus) en España y Portugal. Dirección General para la Biodiversidad, Madrid, Spain.

Hanski, I. (1999) Metapopulation Ecology. Oxford University Press, Oxford, UK.

Jackson, R., Roe, M.J., Wangchuk, R. \& Hunter, D. (2005) Surveying Snow Leopard Populations with Emphasis on Camera Trapping: A Handbook. The Snow Leopard Conservancy, Sonoma, USA.

Karanth, K.U. \& Nichols, J.D. (1998) Estimation of tiger densities in India using photographic captures and recaptures. Ecology, 79, 2852-2862.

Kendall, W.L. \& Bjorkland, R. (2001) Using open robust design models to estimate temporary emigration from capture-recapture data. Biometrics, 57, 1113-1122.

López, G., López-Parra, M., Fernández, L., MartínezGranados, C., Martínez, F., Meli, M. et al. (2009)

Management measures to control a feline leukaemia virus outbreak in the endangered Iberian lynx. Animal Conservation, $12,173-182$.

López-Bao, J.V., Palomares, F., Rodríguez, A. \& Delibes, M. (2010) Effects of food supplementation on home-range size, reproductive success, productivity and recruitment in a small population of Iberian lynx. Animal Conservation, 13, 35-42.

Moreno, S. \& Villafuerte, R. (1995) Traditional management of scrubland for the conservation of rabbits Oryctolagus cuniculus and their predators in Doñana National Park, Spain. Biological Conservation, 73, 81-85.

Moreno, S., Villafuerte, R., Cabezas, S. \& Lombardi, L. (2004) Wild rabbit restocking for predator conservation in Spain. Biological Conservation, 118, 183-193. 
Palomares, F., Delibes, M., Ferreras, P., Fedriani, J.M., Calzada, J. \& Revilla, E. (2000) Iberian lynx in a fragmented landscape: predispersal, dispersal and postdispersal habitats. Conservation Biology, 14, 809-818.

Palomares, F., Delibes, M., Revilla, E., Calzada, J. \& Fedriani, J.M. (2001) Spatial ecology of Iberian lynx and abundance of European rabbits in southwestern Spain. Wildlife Monographs, 148, 1-36.

Palomares, F., Revilla, E., Calzada, J., Fernández, N. \& Delibes, M. (2005) Reproduction and pre-dispersal survival of Iberian lynx in a subpopulation of the Doñana National Park. Biological Conservation, 122, 53-59.

Palomares, F., Rodríguez, A., Laffite, R. \& Delibes, M. (1991) The status and distribution of the Iberian lynx (Felis pardina Temminck) in Coto Doñana area, SW Spain. Biological Conservation, 57, 159-169.

Ruiz, G. (2008) Genetic restocking of Iberian lynx Doñana population. In Proceedings of the III Iberian Lynx Conservation Seminar. Junta Autonoma de Andalucía, 12-14 December 2008, Huelva, Spain. (eds Junta de Andalucía \& IUCN/Cat Specialist Group), pp. 61-64. Junta Autonoma de Andalucía, Huelva, Spain.

Sarmento, P., Cruz, J., Eira, C. \& Fonseca, C. (2009) Evaluation of camera trapping for estimating red fox abundance. Journal of Wildlife Management, 73, 1207-1212.

Schwarz, C.J. \& Arnason, A.N. (1996) A general methodology for the analysis of capture-recapture experiments in open populations. Biometrics, 52, 860-873.

Silveira, L., JÁ Сомо, A.T.A. \& Diniz-Filho, J.A.F. (2003) Camera trap, line transect census and track surveys: a comparative evaluation. Biological Conservation, 114, 351-355.
Simón, M.A. (2008) Current status of Iberian lynx in Andalucía. In Proceedings of the III Iberian Lynx Conservation Seminar. Junta Autonoma de Andalucía, 12-14 December 2008, Huelva, Spain. (eds Junta de Andalucía \& IUCN/Cat Specialist Group), pp. 5-11. Junta Autonoma de Andalucía, Huelva, Spain.

VAn Dyкe, F. (2008) Conservation Biology: Foundations, Concepts, Applications. 2nd ed. Springer, Dordrecht, The Netherlands.

Von Arx, M. \& Breitenmoser-Wursten, C. (2008) Lynx pardinus. In IUCN Red List of Threatened Species. v. 2011.2. Http://www. iucnredlist.org [accessed 11 February 2012].

White, G.C. \& Burnham, K.P. (1999) Program MARK: survival estimation from populations of marked animals. Bird Study, 46, 120-138.

\section{Biographical sketches}

Marcos López-Parra, Leonardo Fernández, Gema Ruiz, and José MARIA GIL-SANCHEZ are wildlife biologists working with the Iberian lynx recovery programme. Their research interests are population monitoring, prey assessment, conservation and lynx translocations. MIGUEL SIMÓN is a wildlife biologist and is currently the Director of the Conservation Programme in Andalusia for the Iberian Lynx (Life Nature). He is responsible for all aspects of lynx conservation in the Autonomous Region. Guillermo López is a veterinarian from the Iberian lynx conservation project in Andalusia. His work focuses on diseases of lynx, particularly feline leukaemia and capture and handling of lynx. PEDRO S ARM EN TO is a wildlife biologist who works mostly on carnivore ecology, with particular research interests in camera trapping, capture-recapture models and conservation planning. 